Bangladesh J. Bot. 41(1): 7-13, 2012 (June)

\title{
OPTIMIZATION OF SULPHUR REQUIREMENT TO SESAME (SESAMUM INDICUM L.) GENOTYPES USING TRACER TECHNIQUES
}

\author{
MMA Mondal ${ }^{* 1,2}$, M Badruddin, MA MaleK ${ }^{3,4}$, MB Hossain ${ }^{5}$ ANd AB PUTEH ${ }^{2}$ \\ Crop Physiology Division, Bangladesh Institute of Nuclear Agriculture (BINA), \\ Mymensingh-2202, Bangladesh
}

Key words: Biochemical activities, ${ }^{35} \mathrm{~S}$ tracer techniques, Sulphur requirement, Sesame yield

\begin{abstract}
Four sesame genotypes viz., T6, SM4, SM7 and SM8 were verified with three levels of sulphur 10, 20 and $40 \mathrm{~kg} / \mathrm{ha}$ including control. Factorial experiment was laid out in a completely randomized design with four replications. Biochemical parameters such as chlorophyll, nitrate reductase, amino acid and total sugar in leaves, total dry mass production, total nitrogen accumulation in seeds and seed yield increased with sulphur application up to $20 \mathrm{~kg} \mathrm{~S} / \mathrm{ha}$. Application of $40 \mathrm{~kg} \mathrm{~S} / \mathrm{ha}$ had no significant benefit on biochemical parameters, dry matter and seed yield of sesame though ${ }^{35} \mathrm{~S}$ uptake in seeds increased with increasing sulphur levels till $40 \mathrm{~kg} / \mathrm{ha}$. The biochemical traits and nutrients uptake were superior in SM4 than other genotypes which resulted in the highest seed yield of SM4. Among the sulphur levels, $20 \mathrm{~kg} \mathrm{~S} /$ ha showed the maximum seed yield in all the genotypes. Therefore, sulphur@20 kg/ha can be recommended for getting maximum productivity of sesame genotypes.
\end{abstract}

\section{Introduction}

Among the oil crops, sesame (Sesamum indicum L.) has the highest oil content of $46-64 \%$ (Raja et al. 2007). In oilseeds, sulphur plays a significant role in the quality and development of seeds. Therefore, crops of oilseeds require a higher quantity of sulphur for proper growth and development for higher yields (Salwa et al. 2010). It is reported that sulphur plays an important role in the primary and secondary plant metabolism as a component of proteins, glucosinolates and other compounds that related to several parameters determining the nutritive quality of crops (Ceccotti 1996, Jamal et al. 2010). The response of oilseeds to sulphur is increasing due to increasing of cropping intensity (Ghosh et al. 2002). Recently, the soils of Indian sub-continent have been reported to be S-deficient and crop response also been reported to S-application (Ghosh et al. 2002, Raja et al. 2007). However, nitrogen and sulphur metabolism are linked to each other. S-application significantly increased the uptake of $\mathrm{N}$ in straw and grain (Badruddin 1999, Fazli et al. 2008) thereby increased grain yield. Further, S-deficiency cause decrease in nitrate reductase activity and in the accumulation of chlorophyll, soluble protein, amino acid and sugar (Tandon 1986, Badruddin 1999, Jamal et al. 2006, Jamal et al. 2009). Thus the synergistic relationship of N and $\mathrm{S}$ in plant metabolism and the maximum yield response to these elements is achieved when the supply of them are balanced in oilseed crops (Jaggi et al. 1977, Badruddin 1999, Fazli et al. 2010). Optimum nutrition, among other agro-techniques is very important for realizing full yield potential and the role of sulfur is next only to nitrogen in the nutrition of this crop. Little effort is made to reclaim optimum $\mathrm{S}$ requirement for the growth and yield of sesame using tracer techniques. Hence this study was attempted to assess the importance of sulphur in biochemical activities, nitrogen and sulphur uptake and yield of sesame genotypes.

\footnotetext{
*Author for correspondence: <ma_mondol@yahoo.com>. ${ }^{1}$ Crop Physiology Division, Bangladesh Institute of Nuclear Agriculture, Mymensingh-2202, Bangladesh. ${ }^{2}$ Department of Crop Science, Faculty of Agriculture, University Putra Malaysia, 43400 UPM Serdang, Selangor, Malaysia. ${ }^{3}$ Plant Breeding Division, Bangladesh Institute of Nuclear Agriculture, Mymensingh-2202, Bangladesh. ${ }^{4}$ Institute of Tropical Agriculture, Universiti Putra Malaysia, 43400 UPM Serdang, Selangor, Malaysia. ${ }^{5}$ Soil Science Division, Bangladesh Institute of Nuclear Agriculture, Mymensingh-2202, Bangladesh.
} 


\section{Materials and Methods}

Pot experiment was conducted in the glasshouse at Bangladesh Institute of Nuclear Agriculture, Mymensingh, Bangladesh in 2007 to 2008. Earthen pots were lined with polyethylene bags. Each pot was filled with $10 \mathrm{~kg}$ sand and the pots were arranged following two factors completely randomized design with four replications. Four variety/mutant lines of sesame viz., T-6 (mother), SM4, SM7 and SM8 were used in this experiment. Ten seeds of each genotype were sown on 05 and 10 March in the year of 2007 and 2008, respectively. After emergence, two seedlings were allowed to grow and the remaining seedlings were removed after seven days of germination. Modified Letcombe nutrient solution (Hewitt 1966) containing @ $1 \mathrm{mM} \mathrm{KH}_{2} \mathrm{PO}_{4}$, $0.092 \mathrm{mM} \mathrm{H}_{3} \mathrm{BO}_{3}, 0.0967 \mathrm{mM}$ Fe-EDTA, $0.0025 \mathrm{mM} \mathrm{CuCl}_{2}, 0.00016 \mathrm{mM} \mathrm{NH}_{4} \mathrm{MO}_{7} \mathrm{O}_{2}, 0.0928$ $\mathrm{mM} \mathrm{MnCl} 2$ and $0.0077 \mathrm{mM} \mathrm{ZnCl}_{2}$ were applied for $\mathrm{P}, \mathrm{B}, \mathrm{Fe}, \mathrm{Cu}, \mathrm{Mo}, \mathrm{Mn}$ and $\mathrm{Zn}$, respectively. To maintain $30 \mathrm{~kg} \mathrm{~N} / \mathrm{ha} \mathrm{KNO}_{3}, \mathrm{Ca}\left(\mathrm{NO}_{3}\right)_{2}$ and $\mathrm{NaNO}_{3} @ 2.5,1$ and $2 \mathrm{mM}$, respectively (jointly equal to $30 \mathrm{~kg} \mathrm{~N} / \mathrm{ha}$ ) were applied each pot as N-source in every week up to maturity.

Sulphur @ 0.15, 0.3 and $0.6 \mathrm{mM}$ for first 6 weeks and 0.225, 0.45 and $0.9 \mathrm{mM}$ for next 6 weeks from $\mathrm{MgSO}_{4}, 7 \mathrm{H}_{2} \mathrm{O}$ were applied to maintain 10,20 , and $40 \mathrm{~kg} \mathrm{~S} / \mathrm{ha}$, respectively. In control (-S) pots, magnesium @ $2 \mathrm{mM}$ from $\mathrm{MgCl}_{2}$ were applied throughout the growing period. Biochemical parameters such as chlorophyll, nitrate reductase, amino acid and total sugar in leaves were determined at reproductive stage. Chlorophyll, nitrate reductase activity (NR), amino acid and total sugar were determined following the method of Yoshida et al. (1976), Stewart and Orebamjo (1979), Badruddin (2005) and Dubois et al. (1956), respectively. Grain nitrogen was estimated by micro-Kjeldahl method (AOAC 1980) and converted to total nitrogen per plant. For S-uptake and transport study, isotope of S was applied in the pot at the above mentioned rates during siliqua filling stage. No ${ }^{35} \mathrm{~S}$ applied in the control pots. For analyses, ${ }^{35} \mathrm{~S}$ extracted by boiling the samples in distilled water in a water bath for 15 minutes and the extract was decanted. The procedure was repeated twice and the radioactivity was counted for 1 minute in a scintillation counter (model LSC 2, NE Technology UK). Biochemical parameters and ${ }^{35} \mathrm{~S}$ isotope uptake were studied only in 2007. The collected data were subjected to statistical analyses as per the design used.

\section{Results and Discussion}

The effect of different levels of sulphur (S) on metabolic activity, growth and yield of sesame was significant (Table 1). Results revealed that chlorophyll, nitrate reductase (NR), amino acid and total sugar were increased with increasing sulphur levels till $20 \mathrm{~kg} / \mathrm{ha}$ followed by a decline. Similar results were also observed in total dry mass (TDM) and seed yield in both the years (Table 1). The highest TDM and seed yield/plant was recorded in $20 \mathrm{~kg} \mathrm{~S} / \mathrm{ha}$ might be due to maximum metabolic activity at this level resulting increased TDM thereby seed yield. The increase in NR activity and chlorophyll content due to $\mathrm{S}$ application might be resulted to the availability of $\mathrm{S}$ in the plant medium that help in producing S-containing amino acid. As a result, synthesis of NR enzyme increased and it enhanced the reduction of $\mathrm{NO}_{3}{ }^{-}$to reduce $\mathrm{N}$ ultimately resulting higher accumulation of sugar thereby increased TDM and seed yield of sesame. Application of S increased TDM and seed yield in oil seed crops as reported by many workers (Nagwari et al. 2001, Amudha et al. 2005, Raja et al. 2007). Furthermore, it is reported that optimum S increased nutrient uptake which help maximum metabolic activity in plants (Badruddin 1999). In the present study, the maximum metabolic activity was observed in $20 \mathrm{~kg} \mathrm{~S} / \mathrm{ha}$ and further increment of S level decreased metabolic activity indicating $20 \mathrm{~kg}$ S/ha was the optimum dose for maximum growth and development of sesame plants as well as yield. It indicates that increase in biochemical substances is somehow related to sulphur application and that might lead increase in TDM as well 
as seed yield of sulphur treated plants over control. It was expected that plants will not thrive in the control at entire growth period but surprisingly plants survived and thrived well up to maturity. This might be due to contamination in the nutrient solution or may be $\mathrm{SO}_{2}$ uptake from air as a scavenger of sulphur. It was reported that plants may also take sulphur as $\mathrm{SO}_{2}$ from the air through stomata (Rennenberg et al. 1979).

Table 1. Effect of sulphur on metabolic activities and yields of sesame genotypes.

\begin{tabular}{|c|c|c|c|c|c|c|c|c|}
\hline \multirow{2}{*}{$\begin{array}{l}\text { Sulphur } \\
\text { levels } \\
\text { (kg/ha) }\end{array}$} & \multirow[t]{2}{*}{$\begin{array}{l}\text { Chlorophyll } \\
\text { (mg/g fw) }\end{array}$} & \multirow{2}{*}{$\begin{array}{c}\text { Nitrate reductase } \\
\left(\mu \mathrm{mol} \mathrm{NO}_{2}^{-} / \mathrm{g}\right. \\
\mathrm{fw})\end{array}$} & \multirow[t]{2}{*}{$\begin{array}{c}\text { Amino acid } \\
(\mathrm{mg} / \mathrm{g} \mathrm{fw})\end{array}$} & \multirow[t]{2}{*}{$\begin{array}{c}\text { Total sugar } \\
(\mathrm{mg} / \mathrm{g} \mathrm{fw})\end{array}$} & \multicolumn{2}{|c|}{$\begin{array}{c}\text { Total dry } \\
\text { mass/plant }(\mathrm{g})\end{array}$} & \multicolumn{2}{|c|}{$\begin{array}{l}\text { Seed yield/ } \\
\text { plant }(\mathrm{g})\end{array}$} \\
\hline & & & & & 2009 & 2010 & 2009 & 2010 \\
\hline 0 & $0.71 \mathrm{c}$ & $1.11 \mathrm{c}$ & $2.89 \mathrm{c}$ & $16.51 \mathrm{c}$ & $3.08 \mathrm{~d}$ & $3.28 \mathrm{~d}$ & $0.26 \mathrm{~d}$ & $0.14 \mathrm{~d}$ \\
\hline 10 & $2.71 \mathrm{~b}$ & $2.92 \mathrm{~b}$ & $4.39 \mathrm{~b}$ & $40.23 \mathrm{~b}$ & $6.50 \mathrm{~b}$ & $9.22 \mathrm{~b}$ & $1.16 \mathrm{c}$ & $1.83 \mathrm{c}$ \\
\hline 20 & $3.03 \mathrm{a}$ & $3.31 \mathrm{a}$ & $5.27 \mathrm{a}$ & $50.47 \mathrm{a}$ & $8.24 \mathrm{a}$ & $11.3 \mathrm{a}$ & $2.00 \mathrm{a}$ & $2.78 \mathrm{a}$ \\
\hline 40 & $2.45 \mathrm{~b}$ & $3.17 \mathrm{ab}$ & $4.64 \mathrm{~b}$ & $42.15 \mathrm{~b}$ & $6.06 \mathrm{c}$ & $8.71 \mathrm{c}$ & $1.27 \mathrm{~b}$ & $1.94 \mathrm{~b}$ \\
\hline F-test & $* *$ & $* *$ & $* *$ & $* *$ & $* *$ & $* *$ & $* *$ & $* *$ \\
\hline CV (\%) & 9.51 & 5.11 & 8.02 & 5.21 & 4.87 & 5.52 & 6.42 & 8.30 \\
\hline
\end{tabular}

Same letter(s) in a column did not differ significantly at $\mathrm{p} \leq 0.05$ by DMRT; $* *=$ Significant at $1 \%$ level of probability.

Isotopic sulfur uptake in seeds by the sesame genotypes was increased with increasing sulphur levels (Fig. 1). However, there was no significant difference in ${ }^{35} \mathrm{~S}$ uptake by seed between 20 and $40 \mathrm{~kg} \mathrm{~S} /$ ha. Similarly, application of sulphur@20 kg/ha had the highest accumulation of $\mathrm{N}$ in seeds (280.2 mg/plant) followed by $40 \mathrm{~kg} \mathrm{~S} / \mathrm{ha}(189.0 \mathrm{mg} / \mathrm{plant})$ (Fig. 1). This result indicated that application of $20 \mathrm{~kg} \mathrm{~S} /$ ha was optimum dose for sesame cultivation. The lowest accumulation of
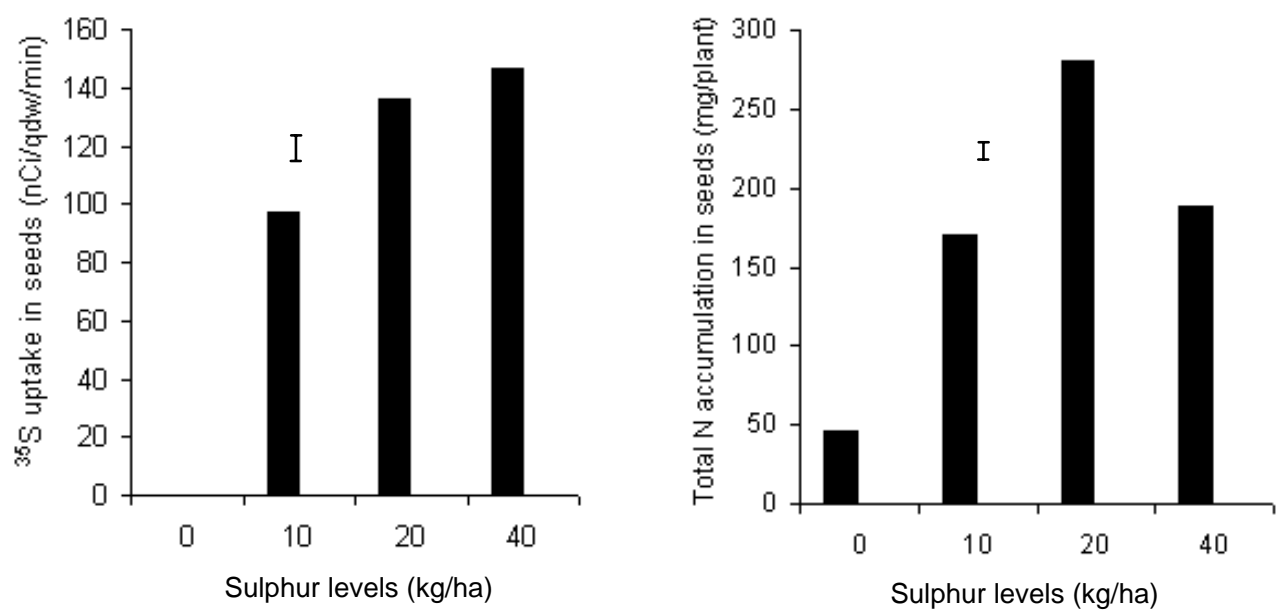

Fig. 1. Effects of sulphur levels on sulphur and nitrogen uptake in grains of sesame genotypes. Vertical bar represents LSD (0.05).

total $\mathrm{N}$ in seeds (46.5 mg/plant) was found in the control. Sulphur and nitrogen are linked to each other in metabolic activity. Control showed the lowest N-metabolism in the seed because no S was supplied there. Judicious application of $\mathrm{S}$ significantly increased the uptake of $\mathrm{N}$ in straw and grain as reported by many workers (Badruddin 1999, Fazli et al. 2008). Furthermore, it was reported that optimum $\mathrm{S}$ increased nutrient uptake which helped maximum metabolic activity in 
plants (Badruddin 1999). In the present study, the maximum metabolic activity was observed in 20 $\mathrm{kg} \mathrm{S} / \mathrm{ha}$ and further increment of $\mathrm{S}$ level decreased metabolic activity indicating $20 \mathrm{~kg} \mathrm{~S} / \mathrm{ha}$ was optimum dose for maximum growth and development of sesame.

Biochemical parameters, ${ }^{35} \mathrm{~S}$ uptake and total $\mathrm{N}$ accumulation in seeds, TDM production and seed yield in sesame except total sugar in leaves were also significantly influenced by different genotypes (Table 2, Fig. 2). The genotype SM4 produced the highest TDM as well as seed yield/ plant due to superiority in biochemical activity in leaves, ${ }^{35} \mathrm{~S}$ uptake and total $\mathrm{N}$-accumulation in seeds. In contrast, the genotype T6 showed the lowest seed yield though it performed lower to medium biochemical activities. Badruddin et al. (2002) reported that uptake of sulphur was higher in high yielding genotypes than those of low yielding ones in sunflower which is in agreement with the present findings. The performance of genotypes was in the following order: SM4> SM7 $>$ SM8 $>$ T6.

Table 2. Genotypic effect on metabolic activities and yields of sesame.

\begin{tabular}{|c|c|c|c|c|c|c|c|c|}
\hline \multirow[t]{2}{*}{$\begin{array}{l}\text { Geno- } \\
\text { types }\end{array}$} & \multirow{2}{*}{$\begin{array}{c}\text { Chloro- } \\
\text { phyll } \\
(\mathrm{mg} / \mathrm{g} \text { fw })\end{array}$} & \multirow{2}{*}{$\begin{array}{c}\text { Nitrate } \\
\text { reductase }(\mu \mathrm{mol} \\
\left.\mathrm{NO}_{2}{ }^{-} / \mathrm{g} \mathrm{fw}\right)\end{array}$} & \multirow[t]{2}{*}{$\begin{array}{c}\text { Amino acid } \\
(\mathrm{mg} / \mathrm{g} \mathrm{fw})\end{array}$} & \multirow[t]{2}{*}{$\begin{array}{l}\text { Total sugar } \\
(\mathrm{mg} / \mathrm{g} \text { fw) }\end{array}$} & \multicolumn{2}{|c|}{$\begin{array}{c}\text { Total dry mass/ } \\
\text { plant }(\mathrm{g})\end{array}$} & \multicolumn{2}{|c|}{$\begin{array}{c}\text { Seed yield/ } \\
\text { plant }(\mathrm{g})\end{array}$} \\
\hline & & & & & 2009 & 2010 & 2009 & 2010 \\
\hline T6 & $2.38 \mathrm{~b}$ & $2.78 \mathrm{ab}$ & $3.87 \mathrm{c}$ & 36.21 & $4.99 \mathrm{c}$ & $7.00 \mathrm{c}$ & $0.77 \mathrm{~d}$ & $1.04 \mathrm{~d}$ \\
\hline SM4 & $3.02 \mathrm{a}$ & $2.95 \mathrm{a}$ & $5.04 \mathrm{a}$ & 38.23 & $8.05 \mathrm{a}$ & $10.3 \mathrm{a}$ & $1.72 \mathrm{a}$ & $2.47 \mathrm{a}$ \\
\hline SM7 & $1.97 \mathrm{c}$ & $2.53 \mathrm{~b}$ & $4.00 \mathrm{~b}$ & 36.80 & $5.96 \mathrm{~b}$ & $7.12 \mathrm{c}$ & $1.16 \mathrm{~b}$ & $1.73 \mathrm{~b}$ \\
\hline SM8 & $1.38 \mathrm{~d}$ & $1.95 \mathrm{c}$ & $4.16 \mathrm{~b}$ & 37.12 & $4.88 \mathrm{c}$ & $8.01 \mathrm{~b}$ & $1.05 \mathrm{c}$ & $1.45 \mathrm{c}$ \\
\hline F-test & $* *$ & $* *$ & $* *$ & NS & $* *$ & $* *$ & $* *$ & $* *$ \\
\hline $\mathrm{CV}(\%)$ & 9.51 & 5.11 & 8.02 & 5.21 & 5.55 & 5.22 & 6.42 & 8.30 \\
\hline
\end{tabular}

Same letter(s) in a column did not differ significantly at $\mathrm{p} \leq 0.05$ by DMRT; $* *=$ Significant at $1 \%$ level of probability; NS = Not significant.
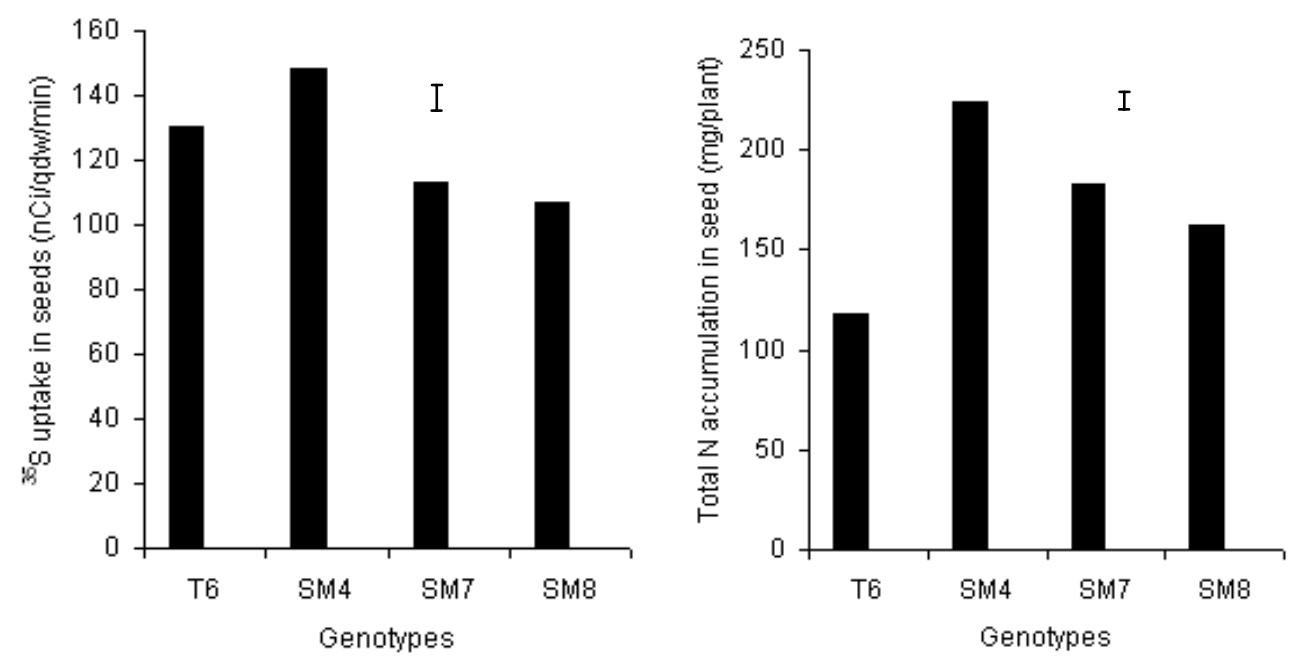

Fig. 2. Genotypic performance on ${ }^{35} \mathrm{~S}$ uptake and total nitrogen accumulation in seeds of sesame. Vertical bar represents LSD (0.05).

Interaction effect between genotypes and sulphur levels showed statistically significant differences in ${ }^{35} \mathrm{~S}$ uptake, total $\mathrm{N}$ accumulation in seeds, TDM production and seed yield of sesame (Table 3). Sulphur utilization by the genotypes was increased with the increase of S levels 
except the genotype T6. In T6, the highest sulphur uptake was observed in $20 \mathrm{~kg} \mathrm{~S} / \mathrm{ha}$. The highest total nitrogen accumulation by the seeds was found in $20 \mathrm{~kg}$ S/ha in all the genotypes except the genotype SM8. In SM8, the maximum total nitrogen accumulation by the seeds was observed at $40 \mathrm{~kg} \mathrm{~S} / \mathrm{ha}$. The lowest nitrogen uptake by the seeds was found in control where no sulphur was applied for all the genotypes. The highest total nitrogen accumulation $(385 \mathrm{mg} / \mathrm{plant})$, total dry mass production (11.6 and $14.3 \mathrm{~g} /$ plant for 2007 and 2008, respectively) and seed yield (3.09

Table 3. Interaction effect of genotypes and sulphur levels on ${ }^{35} \mathrm{~S}$ uptake and total nitrogen accumulation in seeds, total dry mass and seed yield in sesame.

\begin{tabular}{|c|c|c|c|c|c|c|c|}
\hline \multicolumn{2}{|c|}{ Interaction } & \multirow{2}{*}{$\begin{array}{l}{ }^{35} \mathrm{~S} \text { uptake in } \\
\text { seeds } \\
(\mu \mathrm{Ci} / \mathrm{gdw} / \mathrm{min})\end{array}$} & \multirow{2}{*}{$\begin{array}{l}\text { Total nitrogen } \\
\text { accumulation in } \\
\text { seeds } \\
\text { (mg/plant) }\end{array}$} & \multicolumn{2}{|c|}{$\begin{array}{l}\text { Total dry mass/plant } \\
(\mathrm{g})\end{array}$} & \multicolumn{2}{|c|}{$\begin{array}{l}\text { Seed yield/plant } \\
(\mathrm{g})\end{array}$} \\
\hline Genotype & $\begin{array}{l}\text { S level } \\
(\mathrm{kg} / \mathrm{ha})\end{array}$ & & & 2009 & 2010 & 2009 & 2010 \\
\hline \multirow[t]{4}{*}{ T6 } & 0 & 0 & $55 \mathrm{~g}$ & $2.87 \mathrm{i}$ & $3.20 \mathrm{hi}$ & $0.28 \mathrm{j}$ & $0.10 \mathrm{~h}$ \\
\hline & 10 & $108.0 \mathrm{f}$ & $100 \mathrm{f}$ & $4.92 \mathrm{~g}$ & $7.18 \mathrm{~g}$ & $0.77 \mathrm{hi}$ & $1.13 \mathrm{~g}$ \\
\hline & 20 & $148.5 \mathrm{c}$ & $200 \mathrm{~d}$ & $6.95 \mathrm{~d}$ & $10.4 \mathrm{~cd}$ & $1.28 \mathrm{f}$ & $1.91 \mathrm{de}$ \\
\hline & 40 & $135.2 \mathrm{~d}$ & $115 \mathrm{f}$ & $5.23 \mathrm{fg}$ & $7.17 \mathrm{~g}$ & $0.73 \mathrm{i}$ & $1.00 \mathrm{~g}$ \\
\hline \multirow[t]{4}{*}{ SM4 } & 0 & 0 & $50 \mathrm{~g}$ & $4.01 \mathrm{~h}$ & $3.81 \mathrm{~h}$ & $0.24 \mathrm{jk}$ & $0.14 \mathrm{~h}$ \\
\hline & 10 & $118.5 \mathrm{e}$ & $275 d$ & $9.41 \mathrm{~b}$ & $12.4 \mathrm{~b}$ & $1.61 \mathrm{~d}$ & $2.66 \mathrm{c}$ \\
\hline & 20 & $158.0 \mathrm{~b}$ & $385 \mathrm{a}$ & $11.6 \mathrm{a}$ & $14.3 \mathrm{a}$ & $3.09 \mathrm{a}$ & $4.16 \mathrm{a}$ \\
\hline & 40 & $168.5 \mathrm{a}$ & $245 \mathrm{c}$ & $7.18 \mathrm{~d}$ & $10.8 \mathrm{c}$ & $1.93 \mathrm{c}$ & $2.93 \mathrm{~b}$ \\
\hline \multirow[t]{4}{*}{ SM7 } & 0 & 0 & $48 \mathrm{~g}$ & $3.12 \mathrm{i}$ & $2.42 \mathrm{i}$ & $0.34 \mathrm{j}$ & $0.20 \mathrm{~h}$ \\
\hline & 10 & $80.0 \mathrm{~g}$ & $200 \mathrm{~d}$ & $6.05 \mathrm{e}$ & $8.43 \mathrm{f}$ & $1.22 \mathrm{f}$ & $1.83 \mathrm{ef}$ \\
\hline & 20 & $120.0 \mathrm{e}$ & $330 \mathrm{~b}$ & $7.02 \mathrm{~d}$ & $9.93 \mathrm{de}$ & $2.24 \mathrm{~b}$ & $3.00 \mathrm{~b}$ \\
\hline & 40 & $140.1 \mathrm{~cd}$ & $153 \mathrm{e}$ & $7.65 \mathrm{c}$ & $7.28 \mathrm{~g}$ & $0.85 \mathrm{~h}$ & $1.90 \mathrm{de}$ \\
\hline \multirow[t]{4}{*}{ SM8 } & 0 & 0 & $33 \mathrm{~g}$ & $2.32 \mathrm{j}$ & $3.29 \mathrm{hi}$ & $0.16 \mathrm{k}$ & $0.10 \mathrm{~h}$ \\
\hline & 10 & $83.1 \mathrm{~g}$ & $165 \mathrm{e}$ & 5.62 ef & $8.88 \mathrm{f}$ & $1.05 \mathrm{~g}$ & $1.68 \mathrm{f}$ \\
\hline & 20 & $117.2 \mathrm{e}$ & $206 \mathrm{~d}$ & $7.41 \mathrm{~cd}$ & $10.3 \mathrm{~cd}$ & $1.40 \mathrm{e}$ & $2.06 \mathrm{~d}$ \\
\hline & 40 & $120.0 \mathrm{e}$ & $243 \mathrm{c}$ & $4.18 \mathrm{~h}$ & $9.56 \mathrm{e}$ & $1.59 \mathrm{~d}$ & $1.96 \mathrm{de}$ \\
\hline F-test & & $* *$ & $* *$ & $* *$ & $* *$ & $* *$ & $* *$ \\
\hline CV (\%) & & 6.49 & 8.38 & 4.87 & 5.52 & 6.42 & 8.30 \\
\hline
\end{tabular}

Same letter(s) in a column did not differ significantly at $\mathrm{p} \leq 0.05$ by DMRT; $* *=$ Significant at $1 \%$ level of probability.

and $4.16 \mathrm{~g} / \mathrm{plant}$ for 2007 and 2008, respectively) was observed in SM4 with $20 \mathrm{~kg} \mathrm{~S} / \mathrm{ha}$. The lowest value of the above mentioned parameters was observed in SM8 with $0 \mathrm{~kg} \mathrm{~S} / \mathrm{ha}$. The increase in seed yield with $20 \mathrm{~kg} \mathrm{~S} /$ ha was the highest in SM4. Thus, SM4 genotype was more responsive to sulfur than other genotypes. The seed yield was the highest at $20 \mathrm{~kg} \mathrm{~S} / \mathrm{ha}$ with any genotypes was due to increase uptake of $\mathrm{S}$ and $\mathrm{N}$ accumulation that stimulated biochemical activity thereby increased TDM. The lowest seed yield was observed in control plants with any genotype due to lack of sulphur. Furthermore, application of $40 \mathrm{~kg} \mathrm{~S} / \mathrm{ha}$ with any genotype decreased total nitrogen accumulation in seeds due to lower biochemical activity and resulting lower seed yield than $20 \mathrm{~kg} \mathrm{~S} /$ ha indicating $40 \mathrm{~kg} \mathrm{~S} / \mathrm{ha}$ may be toxic for plant growth and development in sesame. Many authors reported that under field condition, the optimum sulphur dose for sesame cultivation was $30-60 \mathrm{~kg} / \mathrm{ha}$ depending on the soil and cultivation techniques (Tandon 1986, Ghosh et al. 2002, Nagwari et al. 2001, Amudha et al. 2005, Raja et al. 2007, Jamal et al. 2010). The present experiment was conducted in sand culture and nutrients were 
applied frequently at 7 days interval up to maturity. As a result, nutrients use efficiency by the plants may be near $70-80 \%$ under sand culture. On the other hand, under field condition, sulphur is applied as gypsum and its use efficiency range $20-40 \%$, depending on land and cultural condition (Jaggi and Sharma 1999). Singh and Saha (1995) reported that $40 \mathrm{~kg}$ S/ha was optimum dose for most of the crops under field condition. Therefore, it can be summarized that sulfur @ 20 $\mathrm{kg} / \mathrm{ha}$ is the optimum dose for sufficient plant growth and development of sesame.

\section{References}

Amudha A, V Vaiyapuri, Sriramachadrasekharam and M Ravichandran 2005. Effect of sulphur and organics on yield and sulphur use efficiency in sesame. Res. Crops 6: 468-470.

AOAC (Association of Official Analytical Chemists) 1980. Official Methods of Analysis. $13^{\text {th }} \mathrm{Ed}$, Washington D.C.

Badruddin M 1999. The effect of sulphur deficiency on ion accumulation with special reference to ${ }^{15} \mathrm{~N}$ and ${ }^{35} \mathrm{~S}$ transport and metabolism in chickpea. Ph.D Thesis, Univ. Dhaka, Bangladesh.

Badruddin M 2005. Laboratory manual for plant and soil sample analysis. Bangladesh Institute of Nuclear Agriculture, Mymensingh, Bangladesh. 25-27 p.

Badruddin M, MMA Mondal, MM Islam and ML Das 2002. Uptake of ${ }^{35} \mathrm{~S}$ by different genotypes of sunflower. Bangladesh J. Agric. Res. 27: 737-740.

Ceccotti SP 1996. Plant nutrition sulphur - A review of nutrient balance, environment impact and fertilizers. Fert. Res. 43: 117-125.

Dubois M, KA Gilles, JK Hamilton, PA Robers and F Smith 1956. Colorimetric method for determination of sugars and related substances. Ann. Chem. 28: 350-356.

Fazli IS, A Jamal, S Ahmad, M Masoodi, JS Khan and MZ Abdin 2008. Interactive effect of sulphur and nitrogen on nitrogen accumulation and harvest in soil seed crops differing in nitrogen assimilation potential. J. Plant Nutr. 31: 1203-1220.

Fazli IS, M Masoodi, S Ahmad, A Jamal, JS Khan and MZ Abdin 2010. Interactive effect of sulphur and nitrogen on growth and yield attributes of oilseed crops. J. Plant Nutr. 33: 1216-1228.

Ghosh PK, KG Mandal, KK Bandhyopadhyay, KM Hati, S Rao and AK Tripathi 2002. Role of plant nutrient management in oilseed production. Fert. News 47: 67-77.

Hewitt EJ 1966. Sand and water culture methods used in the study of plant nutrition. Commonwealth Agriculture Bureaux, Farnham, Royal, England, G. R.

Jaggi RC and RK Sharma 1999. Sulphur response patterns on flowering, dry matter yield and sulphur utilization in Raya (Brassica juncea Varuna) in soils of districts Kangra. J. Indian Soc. Soil Sci. 47: 513 518.

Jaggi RC, MS Aulakh and G Dev 1977. Interaction effect of nitrogen and sulphur on growth and nutrient uptake by maize. J. Nuclear Agric. Biol. 6: 18-20.

Jamal A, IS Fazli, S Ahmed, MZ Abdin and SJ Yun 2006. Effect of nitrogen and sulphur application on nitrate reductase and ATP-sulphurylase activities in soybean. Korean J. Crop Sci. 54: 298-302.

Jamal A, K Ko, HS Kim, TK Cho, H Joung and K Ko 2009. Role of genetic factors and environmental conditions in recombinant protein production for plant molecular biofarming. Biotech. Advan. 27: 914923.

Jamal A, Y Moon and MZ Abdin 2010. Sulphur - a general overview and interaction with nitrogen. Australian J. Crop Sci. 4: 523-529.

Nagwari AVS, Chandrika and Muneendra 2001. Effect of nitrogen and sulphur on yield and oil content of sesame. J. Oilseed Res. 18: 73-77.

Raja A, KO Hattab, L Gurusamy and S Suganya 2007. Sulphur levels on nutrient uptake and yield of sesame varieties and nutrient availability. Int. J. Soil Sci. 2: 278-285.

Rennenberg H, K Schmitz and L Bergmann 1979. Long distance transport of sulphur in Nicotiana tabacum. Planta 147: 57-62. 
Salwa AIE, MA Mohsen and SS Behary 2010. Amelioration productivity of sandy soil by using amino acid, sulphur and micronutrients for sesame production. J. American Sci. 6: 250-257.

Singh MV and JK Saha 1995. A review of the sulphur research activities of the ICAR-AICRP micro and secondary nutrients project. Sulphur Agric. 19: 35-48.

Stewart GR and TO Orebanjo 1979. Some unusual characteristics of nitrate reduction Erythrana senegalensis. New Physiol. 83: 311-319.

Tandon HLS 1986. Sulphur research and agricultural production in India. 2nd ed., Fertilizer Development and Consultation Organization, New Delhi. 18-36 p.

Yoshida S, DA Forno, JA Cock and KA Gomes 1976. Laboratory manual for physiological studies of rice. $3^{\text {rd }}$ ed., IRRI, Los Banos, Philippines.

(Manuscript received on 21 September, 2011; revised on 27 February, 2012) 